\title{
Manajemen Pembelajaran Taḥfiz dalam Peningkatan Minat Menghafal Alquran Siswa di Yayasan Tahfidzul Quran Al- Fawwaz Medan
}

\author{
${ }^{1}$ Candra Wijaya, ${ }^{2}$ M. Fajri Syahroni Siregar, ${ }^{3}$ Muhammad Ruslan, ${ }^{4}$ Syahrul Holid, \\ ${ }^{5}$ Roslaeni \\ Pascasarjana Universitas Islam Negeri Sumatera Utara \\ candrawijaya@uinsu.ac.id, syahronisiregar1404@gmail.com, \\ ibnuaban@gmail.com, syahrulkholid89@gmail.com, leniroslaeni78@gmail.com
}

\begin{abstract}
This study aims to determine the management of learning Tahfiz Alquran which includes planning and organizing learning, implementing the learning and evaluating learning. This research is qualitative with a case study model. The collection method uses observation, interviews and also does documentation. The results showed that: (1) Management of learning Tahfiz Alquran in increasing interest in memorizing the Koran at the Tahfiz Al-Fawwaz Foundation includes: (a) learning planning consisting of memorization targets, learning objectives, learning programs, time allocation to learning tools, (b) learning that has a teaching team organization division and students are also grouped, (c) the implementation of learning which consists of learning activities and learning motivation, (d) learning evaluation.
\end{abstract}

\begin{abstract}
ABSTRAK
Penelitian ini memiliki tujuan untuk mengetahui amanajemen pembelajaran Taḥiz Alquran yang meliputi perencanaan dan pengorganisasian pembelajaran, pelaksanaan pembelajaran tersebut dan evaluasi pada pembelajaran. Penelitian ini termasuk kualitatif dengan model studi kasus. Adapun Metode pengumpulan menggunakan cara observasi, wawancara dan juga melakukan dokementasi. Hasil penelitian menunjukkan bahwa: (1) Manajemen pembelajaran Tahfiz Alquran dalam meningkatkan minat menghafal Alquran di Yayasan Taḥfiz Al-Fawwaz meliputi: (a) perencanaan pembelajaran yang terdiri atas target hafalan, tujuan pembelajaran, program pembelajaran, alokasi waktu sampai pada perangkat pembelajaran, (b) pembelajaran yang memiliki pembagian organisasi tim mengajar dan juga siswa juga dikelompokkan, (c) pelaksanaan pembelajaran yang terdiri atas kegiatan pembelajaran dan motivasi pembelajaran, (d) evaluasi pembelajaran
\end{abstract}

Kata Kunci: Management, Learning, Tahfiz Alquran 


\section{PENDAHULUAN}

(Abdul Majid Khon, 2007: 2) menjelaskan bahwa Alquran itu kalam Allah swt. Kitab suci ini mukjizat yang diturunkan kepada Nabi Muhammad SAW melalui perantara malaikat Jibril. Periwayatan Alquran dilakukan dengan mutawatir dan yang membacanya bernilai ibadah. Alquran merupakan kebenaran yang tidak dapat ditolak. Alquran merupakan kitab petunjuk yang menuntun manusia menjalani kehidupan dengan benar.

Nabi Muhammad saw. menerima dan mengajarkan Alquran melalui cara hafalan. Wahyu yang Allah swt. turunkan kepada Nabi Muhammad saw. dilakukan dengan bertahap. Hafalan merupakan metode terbaik bagi Nabi Muhammad saw. dan para sahabat untuk senantiasa mengingat dan juga memahami makna sehingga ajaran yang terkandung di dalam Alquran dapat di amalkan. Apabila ayat atau surat diturunkan kepada Nabi Muhammad saw., Nabi langsung bersegera menghafalnya dan mengajarkannya kepada para sahabat. Para sahabat menerima ajaran Alquran dan mereka menguasai karena mereka diperintahkan untuk menghafalnya.

Pemeliharaan Alquran dengan metode hafalan ini menjadi suatu ciri khas yang telah dilakukan kalangan para Tabi'in dan seterusnya (Ahsin W. Alhafidz, 1994: 5). Memelihara keaslian Alquran dan menghafalkannya merupakan suatu amal yang terpuji bahkan Nabi Muhammad saw. begitu menganjurkannya.

Menurut (Makhyaruddin, 2013: 49-50), menghafal Alquran tidak saja mengumpulkan huruf-huruf dalam hati, melainkan menjadikan kegiatan menghafal Alquran sebagai ibadah. Mudah-mudahan pahala dan kemudahan hidup bisa di dapatkan karena telah dekat dengan Alquran. Membaca Alquran harus dilakukan dengan baik karena salah pelafalan huruf Alquran bisa merubah makna.
Seseorang yang dapat menghafal Alquran, mendapatkan begitu banyak keistimewaan. Topik ini menurut peneliti urgent untuk diteliti. Pembelajaran Tahfiz Alquran biasanya terdapat di pondok pesantren ataupun madrasah. Untuk lembaga pendidikan sekolah masih jarang atau tidak semua sekolah terdapat pembelajaran tersebut. Sehingga peneliti tertarik untuk meneliti pembelajaran Taḥiż Alquran.

Penyelenggaraan pembelajaran merupakan salah satu tugas utama guru yang dimaksudkan agar tercipta kondisi yang memungkinkan terjadinya belajar pada diri siswa. Suatu kegiatan pembelajaran, terdapat dua aspek penting yaitu proses belajar berupa sejumlah pengalaman intelektual, emosional, spiritual dan hasil belajar berupa perubahan perilaku pada diri siswa. Adapun pembelajaran merupakan suatu aktivitas mengorganisasi untuk mengatur lingkungan dengan baik dan menghubungkannya dengan peserta didik sehingga terjadi proses belajar

Saat ini banyak lembaga pendidikan Islam baik formal maupun non-formal yang melaksanakan pembelajaran Taḥfiz Alquran, salah satunya Yayasan Taḥiz Al-Fawwaz Lembaga ini berusaha membimbing para siswanya untuk cinta terhadap Alquran melalui adanya pembelajaran Tahfiz Alquran. Melalui pembelajaran akan terjadi proses pengembangan moral keagamaan, aktivitas, dan kreativitas peserta didik melalui berbagai interaksi dan pengalaman belajar.

Yayasan Tahfiz yang baik seharusnya telah terdapat sistem manajemen strategis pada setiap programnya. Adapun waktu, lingkungan, dan pendidik yang baik begitu diperlukan dalam sebuah yayasan Tahfiz. Pengelola Taḥiz harus pandai melakukan pengaturan waktu dan program tersebut harus disusun sesuai dengan waktu luang para santri, manajemen tempat, tempat yang nyaman akan membuat otak rileks dalam 
menghafal Alquran, Manajemen pendidik, pendidik atau sering disebut Ustaẓ/Ustazah sebaiknya merupakan orang yang sudah professional di bidang Taḥfizul Qur'an, mengerti tahap-tahap dalam menghafal dan tentunya juga kuasai Tahsin.

Proses menghafal tentu melewati banyak rintangan. Problem dan tantangan orang menghafal Alquran. Adapun tantangan yang dihadapi: pertama, mental (psikologis) bahwa menurut Majdi Faruq Ubaid dalam keberhasilan menghafal Alquran ada sekitar $90 \%$ dari faktor psikologis dan sisanya $10 \%$ karena ketrampilan. Manajemen waktu yang baik juga harus dilakukan oleh penghafal Alquran. Seorang penghafal Alquran juga harus memiliki skala prioritas, sehingga Alquran bisa tertanam pada hatinya dalam menjalani kehidupan dunia. Menghafal Alquran juga harus pada lingkungan penghafal karena lingkungan yang baik juga menjadi modal untuk mendukung menghafal Alquran, apalagi lingkungan menjadikan faktor eksternal saat menghafalnya.

Secara umum masyarakat mengikuti program Taḩiz pada yayasan al-Fawwaz dengan alasan di antaranya, menginginkan anak-anaknya belajar Alquran dan menghafal Alquran tanpa harus ke pesantren. Masyarakat menganggap bahwa pesantren memiliki peraturan yang begitu dan ada beberapa orangtua yang tidak berkenan untuk jauh dari berada anaknya. Penyebab itu yang membuat orangtua mempercayakan pembelajaran Alquran untuk anaknya pada Yayasan Tahfizul Qur'an Al-Fawwaz. Apalagi Pembelajaran Taḥfiz Alquran di yayasan ini mempunyai target hafalan, minimal satu hari satu juz. Agar target dan kemajuan hafalan bisa terpenuhi, tentunya tidak terlepas dari pengelolaan pembelajaran yang bagus. .

Peraturan Pemerintah Republik Indonesia Nomor 13 Tahun 2015 Pasal 19 Ayat 3, memberikan penjelasan bahwa Setiap satuan pendidikan harus membuat perencanaan untuk proses pembelajaran, pelaksanaan proses pembelajaran, penilaian hasil pembelajaran bahkan sampai pada pengawasan proses pembelajaran tersebut agar terlaksananya proses pembelajaran yang efektif dan efisien.

Berdasarkan pernyataan tersebut dapat diketahui bahwa manajemen pembelajaran sangat diperlukan dalam proses pembelajaran. Manajemen tersebut meliputi: planning, organizing, actuating, dan controlling. Manajemen menjadi wajib dilakukan dalam proses pembelajaran agar tercipta susasana pembelajaran yang efektif dan efisien, sehingga tercapai tujuan yang ditentukan. Berdasarkan hal tersebut, peneliti tertarik untuk menggali lebih dalam mengenai Manajemen Pembelajaran Taḥfiz Dalam Peningkatkan Minat Menghafal Alquran Siswa Di Yayasan Taḥfizul Qur'an Al- Fawwaz Medan.

Berdasarkan latar belakang di atas, rumusan masalah yang diajukan dalam penelitian ini adalah sebagai berikut:

1. Bagaimana Manajemen

Pembelajaran Tahfiz Dalam Peningkatkan Minat Menghafal Alquran Siswa Di Yayasan Taḥfizul Qur'an Al- Fawwaz Medan?

2. Apa saja faktor pendukung dan penghambat Implementasi Manajemen Pembelajaran Taḥfiz di Yayasan Tahfizul Qur'an AlFawwaz Medan

3. Bagaimana hasil dari Implementasi Manajemen Pembelajaran Taḥfiz Alquran di Yayasan Taḥfizul Qur'an Al- Fawwaz Medan?

\section{TINJAUAN PUSTAKA}

a. Pengertian Manajemen Pembelajaran Istilah manajemen memiliki banyak arti, adapun istilah manajemen madrasah sering disandingkan pada istilah administrasi madrasah. Terdapat tiga pandangan dalam memberikan arti tentang manajemen. Pertama, mengartikan bahwa manajemen itu inti dari administrasi, kedua, menganggap 
bahwa manajemen lebih luas dari pada administrasi dan ketiga, manajemen identik dengan administrasi.

Manajemen berasal dari kata to manage yang artinya mengatur. Manajemen bisa dikatakan sebagai pengaturan yang dilakukan berdasarkan proses bahkan harus diatur secarasistematis karena memiliki dasar pada urutan dari fungsi-fungsi manajemen. Manajemen merupakan suatu proses untuk mewujudkan tujuan yang diinginkan untuk dicapai. manajemen pada umumnya dikaitkan dengan aktivitas-aktivitas perencanaan, pengorganisasian, pengendalian, penempatan, pengarahan, pemotivasian, komunikasi dan pengambilan keputusan yang dilakukan oleh setiap organisasi dengan tujuan untuk mengkoordinasikan berbagai sumberdaya yang dimiliki (Hasibuan, 2004:1)

Manajemen juga dikatakan sebagai kegiatan wajar dan dilakukan berdasarkan norma yang sudah ada. Adapun pelaksanaannya memiliki hubungan dan saling keterkaitan dengan lainnya. Manajemen dilaksanakan oleh orang atau beberapa orang yang ada dalam organisasi dan diberi tugas untuk melaksanakan kegiatan tersebut.

(Suharsimi Arikunto, 1996: 78) memberikan pendapatnya bahwa manajemen itu pengurusan yang dilakukan agar sesuatu yang dikelola bisa berjalan dengan baik, lancar, efektif dan efisien. Manajemen juga diartikan sebagai proses merencana, mengorganisasi, memimpin dan mengendalikan upaya organisasi dengan segala aspeknya agar tujuan organisasi tercapai secara efektif dan efisien (Nanang Fattah, 2001:1). Maka, manajemen bisa disebut sebagai rangkaian kegiatan yang berproses dan bisa dilaksanakan pada sebuah kegiatan agar tujuan yang telah ditetapkan dan diharapkan dapat tercapai.
Berdasarkan fungsi pokoknya, manajemen dan administrasi mempunyai fungsi yang sama. Adapun perbedaan kedua istilah tersebut tidak signifikan. Manajemen juga bisa dikatakan sebagai proses yang khas, sehingga suatu tujuan bisa tercapai dengan efektif dan efisien karena memakai semua sumber daya. Terry menjelaskan: "Management is performance of coneiving desired result by means of grouuf efforts consisting of utilizing human talent and resources". Ini dapat dipahami bahwa manajemen adalah kemampuan mengarahkan dan mencapai hasil yang diinginkan dengan pemberdayaan manusia dan sumber daya lainnya. (Syafaruddin, 2005: 41)

Adapun UU RI nomor 20 tahun 2003 tentang Sistem Pendidikan Nasional memberikan penjelasan bahwa pembelajaran itu proses interaktif peserta didik dengan pendidik dan sumber belajar pada suatu lingkungan belajar.

(B Suryo Subroto, 1997: 19)

Proses belajar mengajar merupakan proses yang memiliki rangkaian perbuatan guru dan siswa berdasarkan hubungan timbal balik. Pembelajaran berlangsung dengan keadaan edukatif agar tercapai tujuan tertentu. Adapun menurut (E. Mulyasa, 2004: 100) pembelajaran bisa dikatakan sebagai interaksi antara peserta didik dengan lingkungannya sehingga terjadi perubahan perilaku ke arah yang lebih baik.

(Abdul Majid, 2014: 109) menjelaskan bahwa pembelajaran itu upaya untuk membelajarkan seseorang atau kelompok atau kelompok orang melalui berbagai upaya dan berbagai strategi, metode, dan pendekatan kearah pencapaian tujuan yang telah direncanakan. pembelajaran itu suatu perubahan perilaku yang relatif tetap dan merupakan hasil praktek yang diulang- ulang, dibelajarkan bukan diajarkan. 
Berbeda dengan Mayer menjelaskan bahwa pembelajaran adalah sesuatu yang dilakukan oleh guru dan tujuan pembelajaran dengan cara memajukan belajar peserta didik. Dalam pembelajaran tersebut, lebih lanjut dijelaskan bahwa termasuk didalamnya yaitu guru, dosen, metode, strategi, permainan pendidikan, buku, proyek penelitian dan bahan presentasi (Sunhaji, 2013: 17).

Bisa disimpulkan bahwa pembelajaran secara umum diartikan dengan proses yang diselenggarakan oleh guru untuk membelajarkan siswa dalam belajar sebagaimana memperoleh dan memproses pengetahuan, keterampilan dan sikap. Pembelajaran dimaksudkan agar tercipta kondisi yang memungkinkan.

Pembelajaran dapat mencakup semua kegiatan yang memiliki pengaruh langsung pada proses belejar manusia. Pembelajaran bisa berbentuk kejadian yang diturunkan oleh bahanbahan cetak, film, slide gambar, program radio, televisi, bahkan kombinasi dari bahan-bahan itu. Era modern berkembang pembelajaran dengan pemanfaatan berbagai program komputer untuk pembelajaran atau dikenal dengan e-learning dan semenjak wabah COVID-19, banyak lembaga pendidikan baik tingkat sekolah dasar sampai perguruan tinggi menggunakannya.

Manajemen pembelajaran sebagai proses mengelola kegiatan perencanaan, pengorganisasian, pelaksanaan bahkan dilakukkannya evaluasi kegiatan yang terkait pada proses belajar sehingga tujuan pun terpenuhi.

Manajemen pembelajaran begitu penting untuk berjalannya sebuah proses pendidikan. Adanya manajemen pada sebuah proses pembelajaran diharapkan untuk tujuan pembelajaran bisa terpenuhi. Adapun langkahlangkah menjalankan proses pembelajaran bisa dimulai dengan melakukan perencanaan dan diakhiri dengan dibuatnya evaluasi, agar bisa mewujudkan pencapaian tujuan pembelajaran. Pada umumnya dan efektivitas belajar bagi peserta didik dan manajemen pembelajaran yang baik bisa berdampak pada kegiatan pembelajaran yang memiliki arah sehingga mampu menciptakan kondisi pembelajaran yang optimal.

b. Tujuan Manajemen Pembelajaran

$$
\text { Manajemen Pembelajaran }
$$

memiliki tujuan untuk penataan dan pengkajian pada situasi dan kondisi pembelajaran dan berguna untuk mengetahui kekuatan dan kelemahan, peluang dan ancaman. Adapun pencapaian pada suatu tujuan memiliki kaitan dengan kepuasan individu maupun kelompok. Manajemen pembelajaran dilakukan dengan harapan pelaksanaan suatu usaha terencana secara sistematis dan dapat dievaluasi secara benar, akurat dan lengkap sehingga mencapai tujuan secara produktivitas, berkualitas, efektif, dan efisien.

c. Langkah-langkah Manajemen Pembelajaran

1) Perencanaan pembelajaran.

Perencanaan dapat diartikan sebagai proses penyusunan materi pelajaran, penggunaan media pengajaran, penggunaan pendekatan dan metode pengajaran, dan penilaian dalam suatu alokasi waktu yang akan dilaksanakan pada masa tertentu untuk mencapai tujuan yang telah ditentukan (Abdul Majid, 2009: 17). Pada dasarnya perencanaan bias menentukan kegiatan yang dilakukan kedepan. Perencanaan harus memiliki kaitan pada penentuan kegiatan yang dilakukan. Perencanaan harus dibuat diawal, sebelum suatu tindakan dilaksanakan, apalagi 
perencanaan merupakan awal dari segala aspek yang akan dilakukan.

Hal-hal yang perlu diperhatikan oleh seorang guru Tahfiz Alquran untuk merencanakan pembelajaran, yaitu:

a) Menyusun program tahunan dan program semester.

b) Menyusun silabus rencana pembelajaran untuk satu semester yang digunakan oleh guru sebagai pertanggungjawaban profesional pendidik.

c) Menyusun rencana pelaksanaan pembelajaran

2) Adanya Proses Pembelajaran yang berlangsungnya pembelajaran di kelas yang merupakan inti dari kegiatan pendidikan (B Suryo Subroto, 1997: 36). Pelaksanaan proses pembelajaran terjadi karena adanya interaksi guru dengan siswa dalam rangka menyampaikan bahan pelajaran kepada siswa untuk mencapai tujuan pengajaran. Proses pembelajaran yang efektif semestinya menumbuhkan daya kreasi, daya nalar, sehingga memudahkan dalam menghafal Alquran. Pelaksanaan pembelajaran meliputi kegiatan pendahuluan, kegiatan inti dan kegiatan penutup

3) Evaluasi Pembelajaran. Adapun Evaluasi pembelajaran merupakan suatu bagian yang integral dari proses pembelajaran. Tanpa kegiatan evaluasi, guru tidak akan tahu seberapa jauh tujuan pembelajaran Tahfiz Alquran telah tercapai. Untuk dapat mencapai tujuan pembelajaran, siswa melakukan kegiatan belajar Tahfiz Alquran dengan cara sesai dengan kemampuannya. Penilaian dilakukan oleh guru terhadap hasil pembelajaran untuk mengukur tingkat pencapaian kompetensi peserta didik. Evaluasi hasil belajar merupakan evaluasi dengan sasaran hasil belajar. Sasaran tersebut sesuai dengan tujuan pembelajaran, yaitu aspek kognitif, afektif dan psikomotor. Teknik evaluasi hasil belajar dapat ditempuh melalui dua cara yaitu tes dan non tes.

b. Taḥfiz Alquran

Taḥfiz Alquran ini terdiri dari kata taḥfiz dan Alquran. Taḥfiz adalah bentuk masdar dari kata - حيفظ ظٍِتحف حفظ yang mempunyai arti menghafalkan, memelihardan menjaga (Munawwir, 1997: 279). Menurut Kamus Besar Bahasa Indonesia Indonesia hafalan telah masuk ingatan dan dapat mengucapkan diluar kepala (tanpa melihat buku atau catatan lainya. (Suharso dan Ana Retnonengsih, 2005: 160)

Menurut (Zaki Zamani dan Syukron Maksum, 2014, 20-21) bahwa menghafal dalam tataran praktisnya adalah membaca dengan lisan. Sehingga menimbulkan ingatan dalam pikiran dan meresap masuk dalam hati unt uk diamalkan dalam kehidupan sehari-hari. Arti menghafal dalam kenyataan yaitu membaca berulang - ulang sehingga hafal dari satu ayat ke ayat berikutnya, dari satu surat ke surat lainya. Sedangkan Alquran sendiri adalah bentuk mashdar dari dari qara'a yang berarti bacaan. Qara'a juga berarti mengumpulkan atau menghimpun, sesuai namanya Alquran juga berarti himpunan huruf dan kata pada satu ucapan yang rapi.

Tahfiz Alquran dapat didefinisikan sebagai proses menghafal 
materi ayat Alquran dengan terus menerus untuk meresapkan ayat Alquran ke dalam pikiran dengan sengaja, sadar, dan sungguh - sungguh agara selalu ingat, sehingga mengungkapkan kembali diluar kepala tanpa melihat. Bisa disimpulkan bahwa pembelajaran tahfiz Alquran upaya yang dilakukan oleh guru untuk membelajarkan peserta didik dalam menghafal Alquran melalui bimbingan pendidik dengan menggunakan metode tahfiz tertentu dan dalam kurun waktu tertentu.

Tujuan pembelajaran tahfiz Alquran menurut (Ahmad Lutfi, 2009: 168), yakni: 1) Peserta didik bisa paham dan tahu akan arti penting dari kemampuan dalam menghafal Alquran. 2) Peserta didik menjadi terampil menghafal ayat-ayat dan surat-surat yang tertera di dalam Alquran. 3) Peserta didik dapat membiasakan menghafal Alquran dengan melakukan murajaah pada aktivitas sehari-hari. 4) Menumbuhkan, mengembangkan serta mempersiapkan bakat hafiz dan ḥafiẓah pada anak, sehingga nantinya menjadi generasi cendekiawan muslim yang hafal Alquran.

Teknik utama dalam tahfiz Alquran yaitu proses menghafal. Menghafal merupakan suatu aktifitas untuk menanamkan materi pada ingatan, sehingga yang telah di ingat kembali timbul secara harfiah, sesuai dengan materi yang asli. Menghafal merupakan proses mental untuk mencamkan dan menyimpan kesankesan yang nantinya suatu waktu bila diperlukan dapat diingat kembali ke alam sadar. (Syaiful Bahri Djamarah, 2002: 29) Apalagi menghafal menjadi suatu proses mengingat karena seluruh ayat-ayat Alquran yang sudah dihafal diingat kembali secara sempurna tanpa melihat mushaf Alquran.

\begin{abstract}
Pada kegiatan menghafal Alquran, informasi yang baru saja diterima melalui membaca ataupun dengan menggunakan teknik-teknik dalam proses menghafal Alquran. Selain itu ada tiga tahap dalam menghafal Alquran yakni, perekaman, penyimpanan, dan pemanggilan. Perekaman terlihat dikala santri mencoba untuk menghafal ayat-ayat Alquran yang dilakukan secara terus menerus, sehingga pada akhirnya masuk dalam tahap penyimpanan pada otak memori dalam jangka pendek dan jangka panjang. Selanjutnya pada fase pemanggilan memori yang telah tersimpan yaitu disaat santri mentasmi'kan hafalannya dihadapan instruktur.
\end{abstract}

\section{METODE}

Penelitian ini adalah penelitian yang besifat kualitatif. Menurut (Creswell, 2013:4) penelitian kualitatif didefinisikan sebagai metodemetode untuk mengeksplorasi, memahami makna yang dianggap berasal dari masalah sosial atau kemanusiaan. Penelitian yang digunakan yaitu penelitian kualitatif deskriptif. Penelitian kualitatif deskriptif adalah berupa penelitian dengan metode atau pendekatan studi kasus (case study).

Penelitian studi kasus (case study research) adalah penelitian yang berupa penyelidikan mendalam dari berbagai macam informasi terkait beberapa unit atau kasus untuk satu periode atau antar beberapa periode waktu majemuk. Penelitian ini menelaah berbagai karakteristik dari sedikit kasus. Dimana kasus tersebut dapat berupa individu, kelompok, organisasi, pergerakan, peristiwa, atau unit geografis. (Neuman, 2017:47-48)

Penelitian ini memusatkan diri secara intensif pada satu obyek tertentu yang mempelajarinya sebagai suatu kasus. Data studi kasus dapat diperoleh dari 
semua pihak yang bersangkutan, dengan kata lain dalam studi ini dikumpulkan dari berbagai sumber (Nawawi, 2003: 1) Studi kasus yang baik harus dilakukan secara langsung dalam kehidupan sebenarnya dari kasus yang diselidiki. Walaupun demikian, data studi kasus dapat diperoleh tidak saja dari kasus yang diteliti, tetapi, juga dapat diperoleh dari semua pihak yang mengetahui dan mengenal kasus tersebut dengan baik.

Menurut Creswell, prosedurprosedur pengumpulan data dalam penelitian kualitatif, meliputi yaitu observasi, wawancara, dokumentasi

Menurut (Creswell, 2013:287) terdapat strategi-strategi untuk menguji dan memastikan validitas internal antaralain : triangulasi data, member checking, waktu yang lama dan observasi berulang, pemeriksaan oleh sesama peneliti, pola partisipatoris, dan klarifikasi bias peneliti.

\section{HASIL PEMBAHASAN}

4.1 Pengorganisasian Pembelajaran Taḥfiz Alquran di Yayasan Tahfidzul Quran Al-Fawwaz Medan

\subsubsection{Struktur Organisasi Yayasan Tahfidzul Quran Al-Fawwaz Medan}

Untuk mencapai target dalam pelaksanaan program taḥiz Alquran di Yayasan Tahfidzul Qur`an Al-Fawwaz Medan maka disusunlah tupoksi tugas masing-masing persolia yang terlibat dalam program taḥfiz tersebut, yaitu:

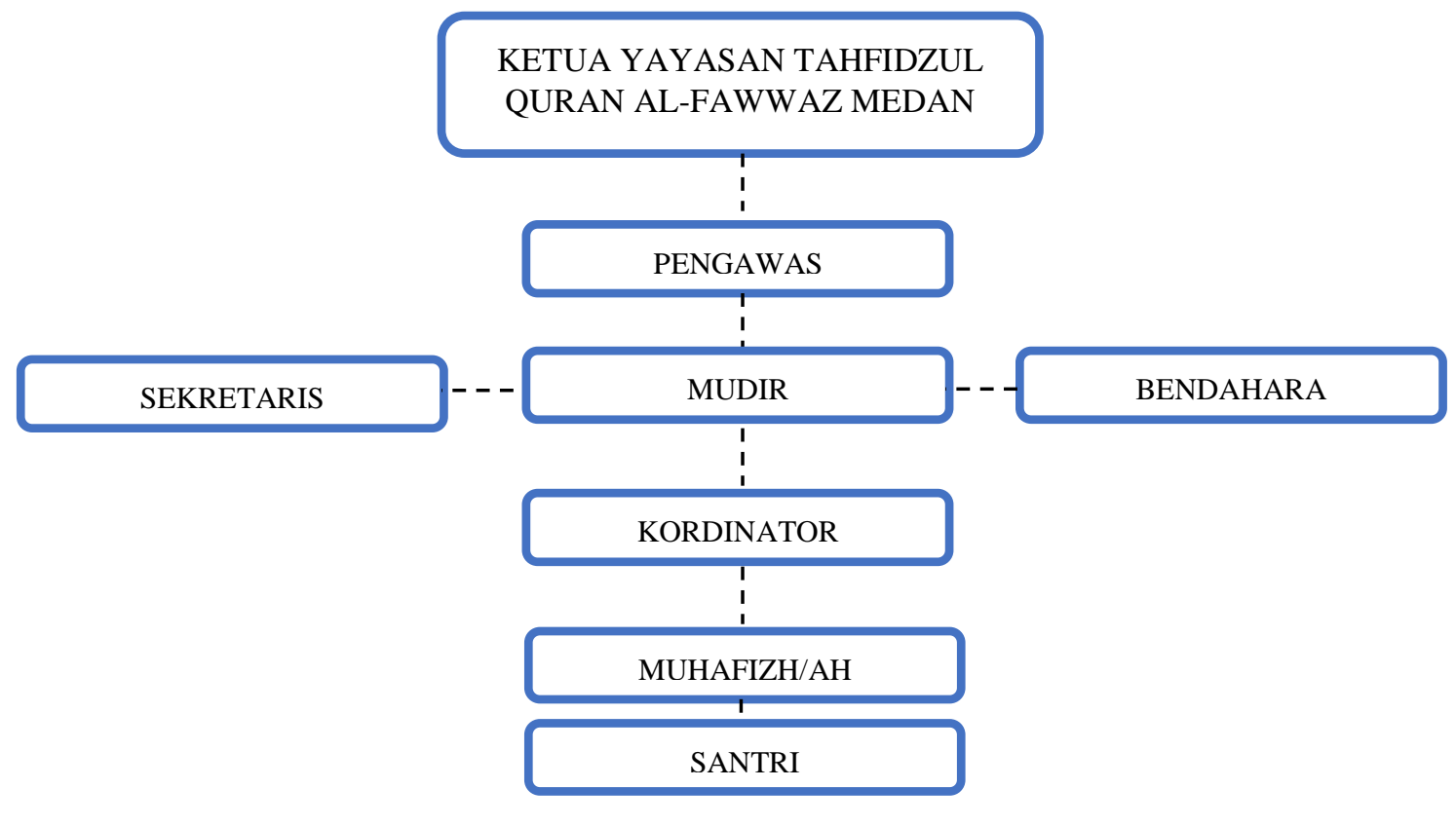

Gambar 1

Struktur organisasi Yayasan Tahfidzul Quran Al-Fawwaz Medan

Keterangan :

Ketua Yayasan

Walil Ketua Yayasan

Pengawas

Mudir

Sekretaris

Bendahara

Kordinator Tahfiz
: H. Tukijan

: Ustaz Zailani S.Pd.I MA

: Ustaz Budi Waskito, ST

Ustaz Azhari, S.Ag

: Ustaz Muhammad Ruslan, M.Pd

: Marhamah, S.Pd

: Sapta Lestari, S.E

: Ustaz Abdul Halim 


$\begin{aligned} & \text { Muhafizh/Muhafizhah } \quad \text { Ustaz Yunus } \\ & \text { Ustazah Rahayu, M.Pd } \\ & \text { Ustazah Saidatun Nisa, M.Pd }\end{aligned}$

Adapun struktur organisasi ini terlihat bahwa tupoksi teratas adalah ketua yayasan yang bertugas Merancang dan menetapkan AD ART, Job Deskripsi, SOP, Kode Etik SDM, aturan kepegawaian, unit usaha, freelance. Konseptor pengembangan usaha-usaha lain sebagai pendukung yayasan. Sedangkan pengawas Mengawasi kelancaran kegiatan yayasan agar sesuai dengan visi dan misi yang telah ditetapkan, Berhak mengawasi alur dana dari Donatur dari luar hasil usaha seperti Hadiah, Hibah, Infaq, Warisan, Wasiat, Wakaf, Sedekah dan dana lain yang tidak mengikat, Menerima serta mengevaluasi laporan pada setiap kegiatan yayasan.

Tugas Mudir adalah Mengatur jadwal kegiatan yayasan baik internal maupun eksternal, Menandatangani surat-surat keluar, surat-surat perjanjian dan kontrak kerja, Bertugas untuk lobi kerjasama dengan lembaga lain, Memimpin Musyawarah Kerja dan Musyawarah Koordinasi, Menandatangani suratsurat berharga yang berhubungan dengan usaha-usaha yayasan, Koordinasi dengan instansi-instansi terkait, Melaksanakan kegiatankegiatan yang bersifat koordinasi dengan SDM Yayasan, Penanggung jawab terhadap inventaris asset, Mengkoordinasikan dan mendelegasikan tugas-tugas kepada pihak ke-3 yang mendukung kesuksesan kegiatan, Perancang kegiatan-kegiatan dan wisuda Pusat Karantina Tahfiż AlquranNasional, Mengemukakan ide inovatif, kreatif dan realisasi untuk kesuksesan kegiatan yayasan.

\section{Sekretaris}

bertugas

Membuat sistem administrasi sesuai dengan standar ISO yang disetujui oleh
Dewan Pembina. Sedangkan bendahara bertugas Mengajukan anggaran operasional yayasan kepada Dewan Pembina. Kordinator program bertugas Menegakkan kedisiplinan peserta dalam pelaksanaan kegiatan taḥiz. Sedangkan tugas muhafizh adalah Menerima setoran hafalan peserta karantina dan memberikan nilai sesuai dengan standarisasi yang sudah ditentukan oleh Yayasan, Mencatat pencapaian prestasi santri setiap kali setoran, Mencatat dan melaporkan rekapan pencapaian harian santri, Mencatat dan melaporkan pelanggaran santri, Menginformasikan peserta yang akan khatmil quran sehari sebelumnya.

\subsubsection{Perencanaan Pembelajaran Tahfiz Alquran di Yayasan Tahfidzul Qur`an Al-Fawwaz Medan}

Perencanaan program tahfiz Alquran yang didirikan oleh Ust Muhammad Ruslan, M.Pd ini dengan tujuan untuk mencetak para penghafal Alquran dengan visi : mewujudkan satu rumah satu penghafal Alquran 2030. Pada awalnya program tahfiz di Yayasan Tahfidzul Qur`an Al-Fawwaz Medan ini diikuti oleh sekitar 20 orang santri yang belum menngunakan metode menghafal yang kekinian atau mutakhir. Perlahan Yayasan Tahfidzul Quran Al-Fawwaz Medan mengadakan langkah strategis dalam merencanakan program Tahfiz yaitu dengan menjalin kemitraan dengan Yayasan Karantina Taḥiz Alquran NAsional (YKTN) yang berada di Kuningan Jawa Barat. Kemudian dilanjutkan dengan menjalin kemitraan dengan penerbit Alquran terbesar milik muslim di Asia yaitu Syaamil Qur’an yang berada di Bandung, Jawa Barat. Setelah menjalin kerjasama tersebuT PROGRAM Taḥfiz di Yayasan Tahfidzul Quran Al- 
Fawwaz Medan mengalami perkembangan yang siginifikan dengan rancangan program yang rapid an teratur. Adapun kerangka rancangan program Tahfiz yang di susun tersebut adalah : Yayasan Tahfidzul Quran mengadakan syiar atau pelatihan membongkar rahasia mudah menghafal Al-Quran baik ke Internal di kalangan santri dan orang tua santri Al-Fawwaz, juga diadakan pelatihan menghafal Alquran di masjid-masjid atau disekolah-sekolah. Setelah masyarakat termotivasi maka diadakan proses seleksi penempetan level kemampuan santri. Proses seleksi tersebut dilaksanakan dengan proses tes kualitas bacaan santri dengan penilian tajwid, fashahah, akhlak dan keseriusan orang tua atau wali santri yang dibuktikan dengan kehadiran orang tua santri mendampingi anaknya ketika mendaftar dan mengikuti seleksi masuk kedalam program. Rancangan berikutnya adalah dengan mengadakan proses taḥfiz Alquran yang diberikan dengan metode tikrar, dan metode ummi. Kemudia tahadapan akhir dari rancangan program tahfiz di Yayaysan Tahfidzul Qur'an Al-Fawwaz Medan adalah dengan mengadakan ujian kenaikan juz dan juga di adakan program wisuda Tahfiz di akhir tahun dengan diserahkan sertifikat tahfiz bagi tiap-tiap peserta sesuai capainnya masing-masing.

Berdasarkan dari hasil pengamatan peneliti di lapangan Yayasan Tahfidzul Qur`an Al-Fawwaz Medan ini sudah berjalan dari 16 Nopember 2018. Program diawali dengan tes masuk asantri baru. Tidak semua pendaftar diterima, namun jika kreteria kemampuannya sudah cukup maka mayoritas peserta didik yang mendaftar diterima dalam program taḥfiz di yayasan Tahfidzul Quran AlFawwaz Medan.

Hasil pengamatan peneliti dalam proses pelaksanaan pembelajaran Tahfiz di Yayasan Tahfidzul Quran Al-Fawwaz santri dibagi kedalam beberapa level. Adapun level-level tersebut adalah sebagai berikut:

Level pra Tahsin

Adapun yang dimaksud dengan level pratahsin adalah para santri yang belum mampu membaca Alquran secara standart tajwid. Kompetensi yang ditargetkan kepada para santri pada level ini adalah membaguskan bacaan Al-Quran sesuai hukum tajwid. Metode yang dipakai dalam level ini ialah dengan menggunakn metode iq'ra. Selain membaguskan bacaan Alquran para santri juga dilatih untuk menghafal surahsurah pendek. Metode menghafal surah-surah pendek tersebut adalah dengan metode ummi.

Level Tahsin

Adapun yang dimaksud dengan level Tahsin adalah kelas yang diperuntukkan bagi para santri yang sudah mampu membaca Alquran namun masih terdapat beberapa kesalan dalam bacaan Alqurannya. Kesalahan tersebut hanya dalam kategori kesalahan ringan (lahn khofi) . Pada level ini para santri sudah diberikan target menghafal namun dengan target yang tidak banyak. Target hafalan yang harus dicapai santri pada level ini adalah 1 maqtha`. 1 Maqtha dalam metode tikrar adalah sebanyak 3-5 ayat yang dihafalkan oleh santri.

Level Tahfiz

Adapun yang dimaksud dengan level taḥfiz ini adalah kelas yang diperuntukkan bagi para 
santri yang sudah mampu membaca Alquran secara benar dalam hukum tajwid. Metode yang diterapkan dalam level ini adalah metode tikrar. Para santri mempersiapkan hafalannya secara optimal ayat yang akan disetorkannya kepada Ustaz.

4.1.3 Pelaksanaan Pembelajaraan Tahfiz Alquran di Yayasan Tahfidzul Quran Al-Fawwaz Medan

Pelaksanaan program Taḥfiz Alquran di Yayasan Tahfidzul Qur`an Al-Fawwaz Medan dilaksanakan dari senin-jumat. Kelas Tahfiz dibagi menjadi dua gelombang. Gelombang pertama dilaksanakan pada pukul 14.00-16.00, sedangkan gelombang kedua dilaksanakan pada pukul 16.0018.00. Santri menyiapkan hafalannya di rumah dengan menggunakan mushaf standart hafalan yaitu mushaf tikrar. Setelah masuk kedalam kelas santri duduk melingkar membentuk halaqah dan guru atau Ustaz diantara mereka. Dalam satu kelas terdapat 10-12 santri yang diserahkan kepada seorang Ustaz untuk dididik. Setelah Ustaz memulai kelas santri mennguatkan kembali hafalannya masing-masing.

Tahapan berikutnya setelah sekitar 10 menit berjalan, Ustaz memerintahkan santri duduk berbaris memanjang kebelakang untuk menyetorkan hafalan ke Ustaz. Ustaz menyimak bacaan santri satu persatu kemudian mencatatkan capaian santri di buku mutaba'ah. Hafalan santri dinyatakan lulus jika tidak ada kesalahan dalam menyetorkan hafalan. Kesalahan yang dapat ditolerir adalah sebanyak tiga kali kesalahan dalam kategori kesalahan ringan.

Tahapan terakhir dalam pelaksanaan tahfiz ini Ustaz memberikan penguatan kepada santri berupa penugasan target hafalan berikutnya.

Berdasarkan hasil pengamatan peneliti dalam program tahfiz di Yayasan Tahfidzul Qur`an Al-Fawwaz Medan dapat diambil gambaran bahwa pelaksanaan program taḥfiz di Yayasan Tahfidzul Qur`an Al-Fawwaz Medan dilaksanakan dengan baik, terancang dan menggunakan metode yang mukhtakhir atau kekinian yaitu metode tikrar, atau metode ummi. Para pendidik di Yayasan Tahfidzul Quran al-Fawwaz tergolong pendidik yang professional. Hal ini terlihat saat pendidik dating tepat waktu dengan kehadiran yang terekap dengan finger print, kompetensi pedagogic yang baik yang mampu menguasai kelas dan mengajar dengan cara yang kreatif dengan mengaitkan ayat-ayat dengan hadist dan kisah-kisah Nabi.

Kekurangan yang terlihat dari program Tahfiz di Yayasan Tahfidzul Qur`an Al-Fawwaz adalah masih terdapat santri yang dating terlabat masuk kelas, capaian hafalan yang tidak sesuai target.

\subsubsection{Evaluasi Pembelajaran Taḥfiz di} Yayasan Tahfidzul Qur`an Al-Fawwaz

Pelaksanaan evaluasi dari hafalan santri dilakukan setelah santri menyetorkan setengah juz. Dalam ujian setengah juz ini santri tidak dibenarkan menambah hafalan baru sebelum hafalan lama benar-benar teruji dihadapan Ustaz. Pelaksanaan evaluasi hafalan berikutnya dilakukan apabila santri sudah menyetorkan 1 juz kepada Ustaznya. Santri di uji oleh Ustaz dan teman-teman sekelasnya dalam program ujian kenaikan juz. Santri yang diuji duduk di depan teman-temannya kemudian setelah dipersilahkan oleh Ustaz santri mengucapkan salm, kemudia menghafalkan sentengah juz lama yang sudah dihafalkannya. Setelah itu Ustaz dan teman sekelasnya memberikan soal sambung ayat kepada santri yang diuji. Setelah santri selesai diuji dalam program ujian kenaikan juz 
Ustaz memberikan penghargaan berupa sertifikat kenaikan juz, pin yang tertulis jumlah juz yang sudah dihafalkan disematkat kebaju santri, tidak lupa juga Ustaz memberikan motivasi kepada santri yang lain agar terus bersemangat menambah dan menjaga hafalan.

Analisis peneliti terhadap pelaksanaan evaluasi pembelajaran taḥiz yang diterapkan di Yayasan Tahfidzul Qur`an Al-Fawwaz Medan ini sangat baik. Hal ini terlihat dari ujian kenaikan juz yang dibuat dua kali dalam setiap juz. Santri yang tampil membacakan hafalannya di depan teman-temannya mampu melatih kepercayaan diri santri untu tampil di depan umum. Hal lain yang sangat efektif adalah pemberian hadiah kepada santri yang sudah menyelesaikan ujian hafalannya sehingga ini menjadi motivasi bagi santri yang lain.

\section{KESIMPULAN}

Berdasarkan hasil penelitian ini peneliti dapat menyimpulkan bahwa Yayasan Tahfidzul Qur`an Al-Fawwaz medan telah menetapkan tupoksi yang jelas terhadap setiap personil yang bertugas dalam pelaksanaan pembelajaran taḥiz Alquran. Dalam pelaksaan pembelajaran Tahfiz Alquran di Yayasan Tahfidzul Qur`an Al-Fawwaz di awali dengan tahapan perencanaan. Dalam tahapan perencaan ini Yayasan Tahfidzul Qur`an Al-Fawwaz Medan telah menyiapkan langkah-langkah yang baik dalam perencaan program taḥfiznya. Hal ini terlihat dengan adanya proses pelatihan dan motivasi taḥfiz, seleksi santi baru sesuai level, pembagian level kelas santri. Tahapan berikutnya adalah pelaksanaan pembelajaran tahfiz di Yayasan Tahfidzul Qur’an Al-Fawwaz dilakasanakan dengan baik, hal ini dibuktikan dengan adanya metode menghafal yang mutakhir dan pembagian kelas yang masuk kategori ideal yaitu 1 guru mengajar 10-12 santri. Dalam tahapan evaluasi program pembelajaran Tahfiz di Yayasan Tahfidzul Qur`an Al-Fawwaz juga dilaksanakan dengan baik, hal ini terlihat ujian kenaikan juz dibagi menjadi dua kali. Hal positif dalam pelaksaan evaluasi ini dapat menguji hafalan santri dan melatih kepercayaan diri santri tampil di depan umum.

Faktor pendukung manajemen pembelajaran Tahfiz Alquran ditetapkannya target hafalan satu Alquran satu bulan dan hal ini menjadi salah satu syarat siswa tersebut lulus. Adanya program matrikulasi. Adapun faktor penghambatnya, yaitu ada guru belum memiliki mental yang kuat saat mengajari siswa, kemudian waktu pembelajaran singkat, dan bacaan Alquran siswa kurang lancar.

$$
\text { Adapun hasil manajemen }
$$
pembelajaran yayasan Tahfiz Al-Fawwaz, yaitu dari keseluruhan siswa yang berjumlah 60 siswa yang sudah mencapai target hafalan satu Alquran 54 anak dengan persentase $90 \%$.

\section{DAFTAR PUSTAKA}

Hasibuan, Malayu. 2004. Manajemen: Dasar, Pengertian, dan Masalah. Jakarta: Bumi Aksara.

Hafidhuddin, Didin dan Hendri Tanjung. 2006. Shariah Principles On Management In Practice. Jakarta: Gema Insani Press.

Undang-undang RI no 20 tahun 2003, Sistem Pendidikan Nasional, Pasal 1, ayat (20)

Subroto, B. Suryo. 1997. Proses Belajar Mengajar di Sekolah. Jakarta: Rineka Cipta.

E Mulyasa. 2004. Kurikulum Berbasis Kompetensi. Bandung: Remaja Rosdakarya.

Majid, Abdul. 2014. Belajar dan Pembelajaran Pendidikan Agama Islam. Bandung: PT. Rosda Karya.

Thobron, Muhammad dan Arif Musthofa. 2011. Belajar dan Pembelajara Pengembangan Wacana dan Praktek Pembelajaran dalam Pembangunan Nasional. Yogyakarta: Ar-Ruz Media. 
Sunhaji. 2013. Pembelajaran Tematik Integratif: Pendidikan Agama Islam dengan Sains. Purwokerto: Stain Press.

Munawir, A. W. 1997. Kamus Arab Indonesia. Surabaya : Pustaka Progresif.

Suharso dan Ana Retnonengsih. 2005. Kamus Besar Bahasa Indonesia. Semarang: Widya Karya.

Zamani dan Sukron Maksum, 2004. Metode Cepat Menghafal Al Quran. Yogyakarta : Al Barokah.

Lutfi, Ahmad. 2009. Pembelajaran Al-Quran dan Hadits. Jakarta: Direktorat Jenderal Pendidikan Islam.

Djamarah, Syaiful Bahri. 2002. Psikologi Belajar. Jakarta: PT. Rineka Cipta.

Khon, Abdul Majid. 2007. Praktikum Qira'at: Keanehan Bacaan Alquran Qira'at Ashim dari Hafash. Jakarta: Amzah.

Makhyaruddin, Deden M. 2013. Rahasia Nikmatnya Menghafal Alquran. Bandung: Mizan.

Alhafidz, Ahsin W. 1994. Bimbingan Praktis Menghafal Alquran. Jakarta: Bumi Aksara.

Creswell, John W. 2013. Research Design: Qualitative and Quantitative Approach. California: Sage Publication.

Nawawi, H. Hadari. 2003. Manajemen Sumber Daya Manusia Untuk Bisnis Yang Kompetitif, Cetakan ke-7. Gadjah Mada University Press, Yogyakarta. 